\title{
REVISTA
}

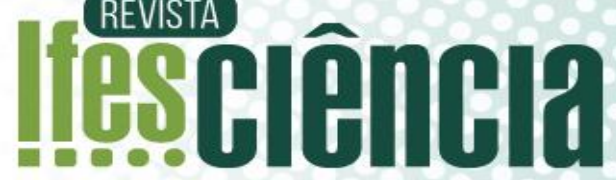

\section{INFLUENCIA DA INFRAESTRUTURA ESCOLAR NO DESEMPENHO EDUCACIONAL: ESTUDO DE CASO NA EEEFM HONÓRIO FRAGA, COLATINA/ES}

\section{INFLUENCE OF THE SCHOOL INFRASTRUCTURE ON EDUCATIONAL PERFORMANCE: CASE STUDY AT EEEFM HONÓRIO FRAGA, IN COLATINA/ES}

\author{
${ }^{1}$ Leonan Stôcco Braido \\ ${ }^{2}$ Elizabete Gerlânia Caron Sandrini
}

${ }^{1}$ Instituto Federal do Espírito Santo - Campus Colatina. E-mail:leonansb@ hotmail.com

${ }^{2}$ Instituto Federal do Espírito Santo - Campus Colatina. E-mail:egerlania@ifes.edu.br

Artigo submetido em 17/06/2020, aceito em 15/07/2020 e publicado em 28/08/2020.

Resumo: Este artigo discute a influência da infraestrutura no desempenho educacional dos discentes da EEEFM Honório Fraga, em Colatina/ES, por meio de um estudo de caso. A escola passou por duas mudanças de infraestrutura, migrando, em 2010, do prédio escolar com poucas condições de infraestrutura para um galpão provisório. Dois anos depois, em 2012, a escola voltou a funcionar no prédio reconstruído. Assim, este estudo teve por objetivo verificar a influência da mudança de infraestrutura no desempenho educacional dos discentes. Para tanto, foram aplicados questionários. Houve, ainda, estudo documental e relatórios fotográficos. Sendo os referenciais teóricos: relatórios do Pisa, indicadores educacionais, Constituição Federal, Lei de Diretrizes e Bases da Educação Nacional e relatórios da Unesco.

Palavras-chave: infraestrutura; desempenho educacional; estudo de caso.

Abstract: This article discusses the influence of infrastructure on the educational performance of students at EEEFM Honório Fraga, in Colatina / ES, through a case study. The school underwent two infrastructure changes, migrating, in 2010, from the school building with poor infrastructure conditions to a temporary warehouse. Two years later, in 2012, the school returned to work in the reconstructed building. Thus, this study aimed to verify the influence of infrastructure change on the educational performance of students. For that, questionnaires were used. There was also a documentary study and photographic reports. Theoretical references are: Pisa reports, Federal Constitution, National Education Guidelines and Bases Act and Unesco reports.

Keywords: infrastructure; educational performance; case study.

\section{INTRODUÇÃO}

Em 2015, foi aprovada, durante o Fórum Mundial de Educação, a Agenda 2030 para o Desenvolvimento Sustentável, sendo 17 objetivos traçados e 169 metas em diversas áreas como: garantia da saúde, do trabalho e da educação, erradicação da 
pobreza e da fome, dentre outros (UNESCO, 2015). O objetivo 4 disserta sobre educação:

Assegurar a educação inclusiva e equitativa e de qualidade, e promover oportunidades de aprendizagem ao longo da vida para todos (UNESCO, 2015, p.23).

Sendo a meta 4.a:

Construir e melhorar instalações físicas para educação, apropriadas para crianças e sensíveis às deficiências e ao gênero, e que proporcionem ambientes de aprendizagem seguros e não violentos, inclusivos e eficazes para todos (UNESCO, 2015, p.23).

Embora apenas a infraestrutura física adequada e o suprimento de recursos educacionais não garantam uma boa aprendizagem, a ausência de tais elementos pode afetar negativamente o desempenho dos alunos. O que importa para uma boa aprendizagem não é necessariamente a disponibilidade dos recursos, mas, também, a qualidade deles e como efetivamente são usados (GAMORAN, SECADA E MARRETT, 2000).

Além da infraestrutura, fatores como o investimento nos professores (bons salários, qualificação profissional), a relação da quantidade alunos/professor, o currículo escolar, as atividades extracurriculares, são imprescindíveis para o desempenho escolar dos alunos. No entanto, o último resultado do Programa Internacional de Avaliação de Aluno (Pisa, sigla em inglês), em relação à infraestrutura, revelou que em 46 países os diretores relataram que a capacidade da escola de fornecer um bom aprendizado foi prejudicada pela falta ou inadequação de material educacional e infraestrutura física.

A Figura 1, referente à Organização para a Cooperação e Desenvolvimento Econômico (OCDE, 2013), evidencia opiniões de diretores de alguns desses países acerca do assunto, validadas em índices numéricos.

Figura 1: Opiniões dos diretores das escolas sobre adequação da infraestrutura física

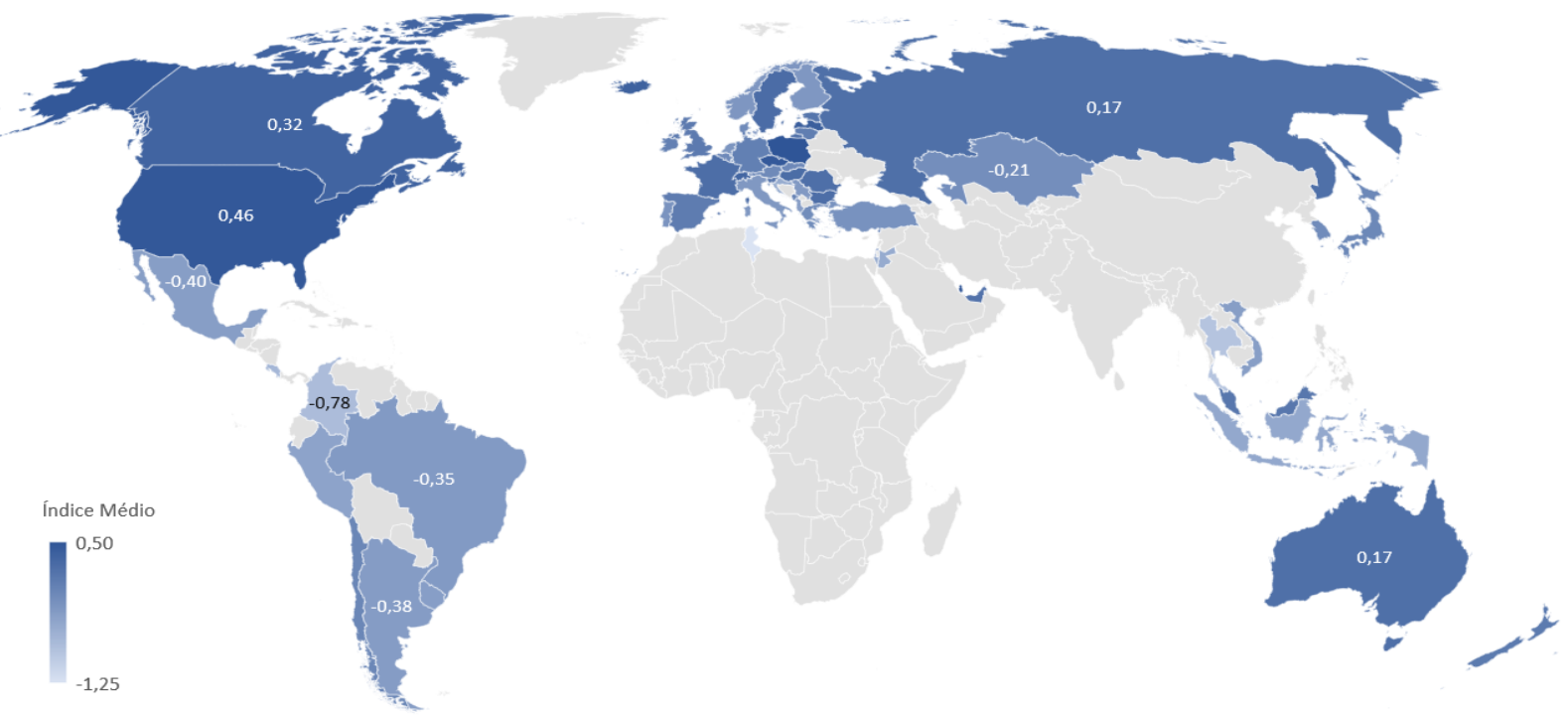

Fonte: Adaptado de OCDE (2013)

O índice para análise foi considerado em termos de positividade e negatividade, sendo o índice zero considerado como adequado, cor azul, 
acima de zero mais do que adequado, cor azul mais forte, e abaixo de zero inadequado, cor azul bem mais clara. No Continente Americano, onde está localizado o Brasil, dois países da América do Norte apresentam índices mais do que suficientes: Canadá com 0,32; Estados Unidos com 0, 46. Em contrapartida, os outros quatro países destacados, três da América do Sul e um da América do Norte, estão com índice inadequado. Entre eles, o Brasil, com -0,35, seguido da Argentina -0,38, México -0, 40 e da Colômbia -0, 78 . $\mathrm{Na}$ Ásia, o Cazaquistão tem índice de -0 , 21. Notório se faz a percepção de que a maioria dos países de menor índice de infraestrutura são países em desenvolvimento.

De acordo com o relatório do Pisa (OCDE, 2013), 33\% da variação do desempenho de matemática nos países da OCDE pode ser explicado pelas diferenças na infraestrutura, como laboratório de ciências, biblioteca, entre outros. Em escolas de melhor desempenho, os diretores informaram $\mathrm{o}$ alto nível de qualidade da infraestrutura física e dos recursos educacionais. Os diretores de escola no Brasil alegaram que a variação entre escolas na qualidade da infraestrutura física e seus efeitos sobre o desempenho escolar é notável.

Tendo em vista as considerações supracitadas acerca da participação da infraestrutura escolar no processo de ensino-aprendizagem dos alunos, configurou-se como problema de pesquisa: de que forma a infraestrutura escolar influencia no desempenho educacional?

Formulado o problema, teve-se por objetivo geral discutir a correlação entre a infraestrutura escolar com o desempenho dos alunos, em um estudo de caso realizado na Escola Estadual de Ensino Fundamental e Médio (EEEFM) Honório Fraga. Isso pelo fato de ter ocorrido mudanças bruscas na infraestrutura do prédio escolar. Tais modificações acabaram por fazer com que houvesse a transição, a saída da infraestrutura do prédio escolar, que não atendia mais às demandas e necessidade de espaço físico, em 2010, para um galpão provisório. Tempos depois, em 2012, uma nova mudança, ou seja, o retorno para a escola "antiga", porém agora totalmente reconstruída, com nova infraestrutura.

\section{REFERENCIAL TEÓRICO}

\subsection{INFRAESTRUTURA}

A preocupação com qualidade da educação teve início na década de 1940, com uma demanda por escolarização das crianças. Era claro, já naquela época, a relação entre qualidade da educação e infraestrutura escolar (UNESCO, 2019).

A infraestrutura escolar foi tida, em estudos realizados, como importante fator no processo de ensino e aprendizagem, pois conservação do prédio escolar, os equipamentos, os recursos escolares, mesmo não sendo os únicos de grande influência, são necessários para um melhor desempenho escolar dos alunos. (ALVES; FRANCO, 2008).

Há ainda uma grande diferença na infraestrutura entre escolas públicas e privadas e também no desempenho educacional proporcionado por ambas. Baseado nos dados do Pisa (OCDE, 2013) em relação a opiniões dos diretores das escolas sobre adequação da infraestrutura física, o Brasil é a terceira maior diferença, dos países avaliados, entre a infraestrutura das escolas públicas em relação às privadas $(-1,36)$, ficando acima apenas da Albânia ($1,59)$ e da Costa Rica $(-1,54)$. Sendo que $38,9 \%$ dos diretores de escolas públicas no Brasil relataram que o desempenho estudantil foi prejudicado, pelo menos em parte, por uma infraestrutura física inadequada ou insuficiente (OCDE, 2019).

Outro parâmetro relevante é o tamanho das escolas. Escolas pequenas, com menos de 50 alunos, possuem um desempenho pior que escolas com mais 
que 400 alunos, pois a maioria das instituições de ensino menores possui infraestrutura pior que as escolas maiores. Não sem motivo, os maiores indicadores do Índice de Desenvolvimento da Educação Básica (Ideb) estarem concentrados nas escolas que possuem melhores infraestruturas (UNESCO, 2019).

\subsection{MARCOS LEGAIS}

A Constituição Federal (CF) de 1988, em seu Art. 206, valida os princípios norteadores para a educação, dentre os quais, no contexto da infraestrutura escolar, se destacam: "igualdade de condições para o acesso e permanência na escola;" e "garantia de padrão de qualidade;" em que os aspectos da infraestrutura estão intrinsicamente ligados, seja quanto à acessibilidade ou à qualidade do ensino (BRASIL, 1988).

Outrossim, a importância da qualidade do ensino é ressaltada na Lei de Diretrizes e Bases da Educação Nacional (LDBEN) n. 9.394, de 20 de dezembro de 1996:

Art. $4^{\circ}$ - O dever do Estado com educação escolar pública será efetivado mediante a garantia de:

\section{$[\ldots]$}

IX - Padrões mínimos de qualidade de ensino, definidos como a variedade e quantidade mínimas, por aluno, de insumos indispensáveis ao desenvolvimento do processo de ensino-aprendizagem (BRASIL, 1996).

A relação entre infraestrutura e qualidade da educação também está prevista na Resolução do Conselho Nacional de Educação (CNE) n.4, de 13 de julho de 2010:

Art. 9 - A escola de qualidade social adota como centralidade o estudante e a aprendizagem, o que pressupõe atendimento aos seguintes requisitos:

[...]

VI - Compatibilidade entre a proposta curricular e a infraestrutura entendida como espaço formativo dotado de efetiva disponibilidade de tempos para a sua utilização e acessibilidade.

[...]

Art. 10 - A exigência legal de definição de padrões mínimos de qualidade da educação traduz a necessidade de reconhecer que a sua avaliação associa-se à ação planejada, coletivamente, pelos sujeitos da escola.

\section{[...]}

$\S 2^{\circ}$ Para que se concretize a educação escolar, exige-se um padrão mínimo de insumos, que tem como base um investimento com valor calculado a partir das despesas essenciais ao desenvolvimento dos processos e procedimentos formativos, que levem, gradualmente, a uma educação integral, dotada de qualidade social:

I - Creches e escolas que possuam condições de infraestrutura e adequados equipamentos.

(CNE, 2010, p. 3).

Em 2014, a então presidente do Brasil, a senhora Dilma Vana Rousseff, aprovou o Plano Nacional de Educação (PNE), em vigor, que estabelece a melhoria da infraestrutura das escolas como uma das estratégias para avançar no desempenho educacional. A estratégia 7.18, da Meta 7 do PNE, ressalta os pontos da infraestrutura que devem ser atendidos pela educação básica:

7.18. Assegurar a todas as escolas públicas de educação básica o acesso a energia elétrica, abastecimento de água tratada, esgotamento sanitário e manejo dos resíduos sólidos, garantir o acesso dos alunos a espaços para a prática esportiva, a bens culturais e artísticos e a equipamentos e laboratórios de ciências e, em cada 
edifício escolar, garantir a acessibilidade às pessoas com deficiência (BRASIL, 2014).

Em maio de 2015, um Grupo de Trabalho (GT) foi criado com objetivo de elaborar estudos para a execução das metas do PNE. Dessa forma, surgiu um relatório com "ideias preliminares a respeito de Parâmetros Nacionais de Qualidade para a Oferta da Educação Básica", contendo seis dimensões principais: 1) acesso; 2) jornada escolar; 3) profissionais; 4) instalações e recursos escolares; 5) democracia; e 6) redes de relações (GT CAQ, 2015).

A dimensão 4 - Instalações e recursos escolares - disserta sobre a infraestrutura (GT CAQ, 2015, p. 48):

Princípios: creche ou escola deve dispor de instalações que abriguem adequadamente as atividades previstas para a jornada escolar e ofereçam condições de trabalho aos profissionais que nela atuam, com acesso aos equipamentos e aos recursos educacionais necessários, atualizados, disponíveis para o uso coletivo e individual com a frequência recomendada pela melhor técnica pedagógica. Estes recursos não precisam obrigatoriamente estar no prédio escolar, podendo também ser garantidos em outros equipamentos no território.

Referenciais: nesta dimensão da qualidade encontram-se sob exame as instalações da escola - salas de aula, refeitório, cozinha, banheiros, biblioteca, sala de professores, luz, água, coleta de lixo - e os equipamentos disponíveis computadores, projetores, mobiliário, fibra óptica, antenas - e os recursos educacionais - livros didáticos, biblioteca, recursos digitais.

Portanto, os aspectos legais vigentes enfatizam, dentre outros, quais parâmetros da infraestrutura devem ser considerados para atender uma boa qualidade de ensino.

\subsection{HISTÓRICO DA EEEFM HONÓRIO FRAGA}

A Escola Estadual de Ensino Fundamental e Médio (EEEFM) Honório Fraga, situada no município de Colatina, no estado do Espírito Santo, foi fundada em 1962 pelo Padre Fulgêncio do Menino Jesus. Na época, a escola não possuía denominação própria, era um anexo da Escola "Conde de Linhares" (BRAIDO et al., 2019).

Após ganhar autonomia, o anexo passou a se chamar "Ginásio São Silvano", funcionando próximo à Matriz do Imaculado Coração de Maria, onde era o colégio "Passionista". Por meio da Lei n. 2.436, de 08 de agosto de 1969, surgiu, então, a "Escola de $1^{\circ}$ Grau Honório Fraga", em homenagem ao ex-prefeito da cidade. E em 1981, a instituição foi transformada em Escola de $1^{\circ}$ e $2^{\circ}$ graus Honório Fraga, por meio da Portaria E n. 1.660, de 23 de dezembro de 1981 (BRAIDO et al., 2019).

No final da última década do século passado, especificamente em 1999, por decisão governamental, os cursos profissionalizantes foram extintos das escolas públicas, e com a aprovação da Lei de Diretrizes e Bases da Educação Nacional n. 9394, de 20 de dezembro de 1996, a escola passou a ter denominação de EEEFM Honório Fraga (BRAIDO et al., 2019).

Em setembro de 2010, ocorreu a mudança de endereço da escola para a avenida Silvio Avidos, em um galpão provisório, para que a reconstrução da escola fosse realizada. De setembro de 2010 a novembro de 2012, aconteceram as obras de reconstrução. Após a conclusão, houve uma nova mudança, para a estrutura reconstruída da escola (BRAIDO et al., 2019).

Atualmente a EEEFM Honório Fraga oferece ensino fundamental final, ensino médio e cursos pós-médio de 
Informática, de Língua Brasileira de Sinais (Libras) e de Recursos Humanos (BRAIDO et al., 2019).

\section{PROCESSOS METODOLÓGICOS}

Em relação à abordagem, esta é uma pesquisa quantitativa e qualitativa, pois se buscou identificar numericamente os indicadores apresentados para análises de correlações. Trata-se também de uma pesquisa aplicada, já que possui implicações diretas na realidade atual, e é uma análise exploratória, que possui como principal objetivo descoberta de intuições (GIL, 2008).

Quanto aos procedimentos, foi elaborado um estudo de caso, definido como a investigação de um fenômeno atual, dentro de um contexto particular, com definição de limitações claramente definidas (GIL, 2008). O estudo de caso foi relativo a uma comparação de diversos aspectos da EEEFM Honório Fraga divido em suas três fases distintas: antes de setembro de 2010, durante o galpão provisório e após novembro de 2012.

Foi aplicado um questionário fechado, que é definido como um método de investigação de questões submetidas a uma parcela populacional com o objetivo de se obter informações pertinentes ao estudo proposto (GIL, 2008). O públicoalvo foi composto por discentes, docentes, servidores e ex-alunos da EEEFM Honório Fraga. O questionário foi aplicado com intuito de se fazer uma leitura da percepção do público-alvo no que se refere à correlação do desempenho escolar com a mudança de infraestrutura. Devido ao distanciamento social necessário, uma vez que o mundo encontra-se envolto pela pandemia do novo Coronavírus - Covid $19^{1}$, o questionário, composto por 10

\footnotetext{
1 A Covid-19 é uma doença causada por um vírus família do vírus Corona $(\mathrm{CoV})$. Os vírus dessa família causam desde resfriados comuns a doenças mais graves, como a Síndrome Aguda Respiratória Severa (SARS) e a Síndrome Respiratória do
}

perguntas, foi respondido online. Computou-se, após o acesso dos participantes, um universo de 104 respostas, sendo 42 respostas de funcionários e ex-funcionários e 62 de alunos e ex-alunos.

Houve ainda a aplicação de um questionário aberto, que pede aos participantes respostas com uma maior liberdade (GIL, 2008). Este foi aplicado a alguns funcionários e ex-funcionários, a fim de se obter uma percepção mais subjetiva da qualidade da infraestrutura. Com três perguntas aplicadas às diversas "fases" que a EEEFM Honório Fraga teve, sendo: "Como você avalia a infraestrutura do prédio escolar da EEEFM Honório Fraga antes de 2010? que aspectos da infraestrutura eram bons? e quais eram ruins?". As perguntas foram repetidas, porém voltadas à infraestrutura do galpão provisório e da escola reconstruída.

Em relação ao aspecto da infraestrutura, foram comparadas as dimensões definidas semelhantemente ao estudo elaborado pela Unesco em parceria com a UFMG "Qualidade da infraestrutura das escolas públicas do ensino fundamental no Brasil", que define seis dimensões em um modelo teórico: "(i) área; (ii) condições de atendimento; (iii) condições básicas; (iv) condições pedagógicas, (v) condições para o bem-estar; e (vi) condições para a equidade". Conforme mostra a Figura 2 (UNESCO, 2019, p. 26).

Oriente Médio (MERS). A Organização Mundial da Saúde (OMS) denominou o Novo Coronavírus de SARS-CoV-2. Desse modo, a doença que ele provoca recebeu a denominação de Covid-19, senod que o numeral da sigla é referente ao ano em que a epidemia teve início. Cabe ressaltar que o surgimento da doença deu-se em Wuhan, na China (GRUBER, 2020). 
Figura 2: Síntese do modelo conceitual para avaliar a infraestrutura das escolas

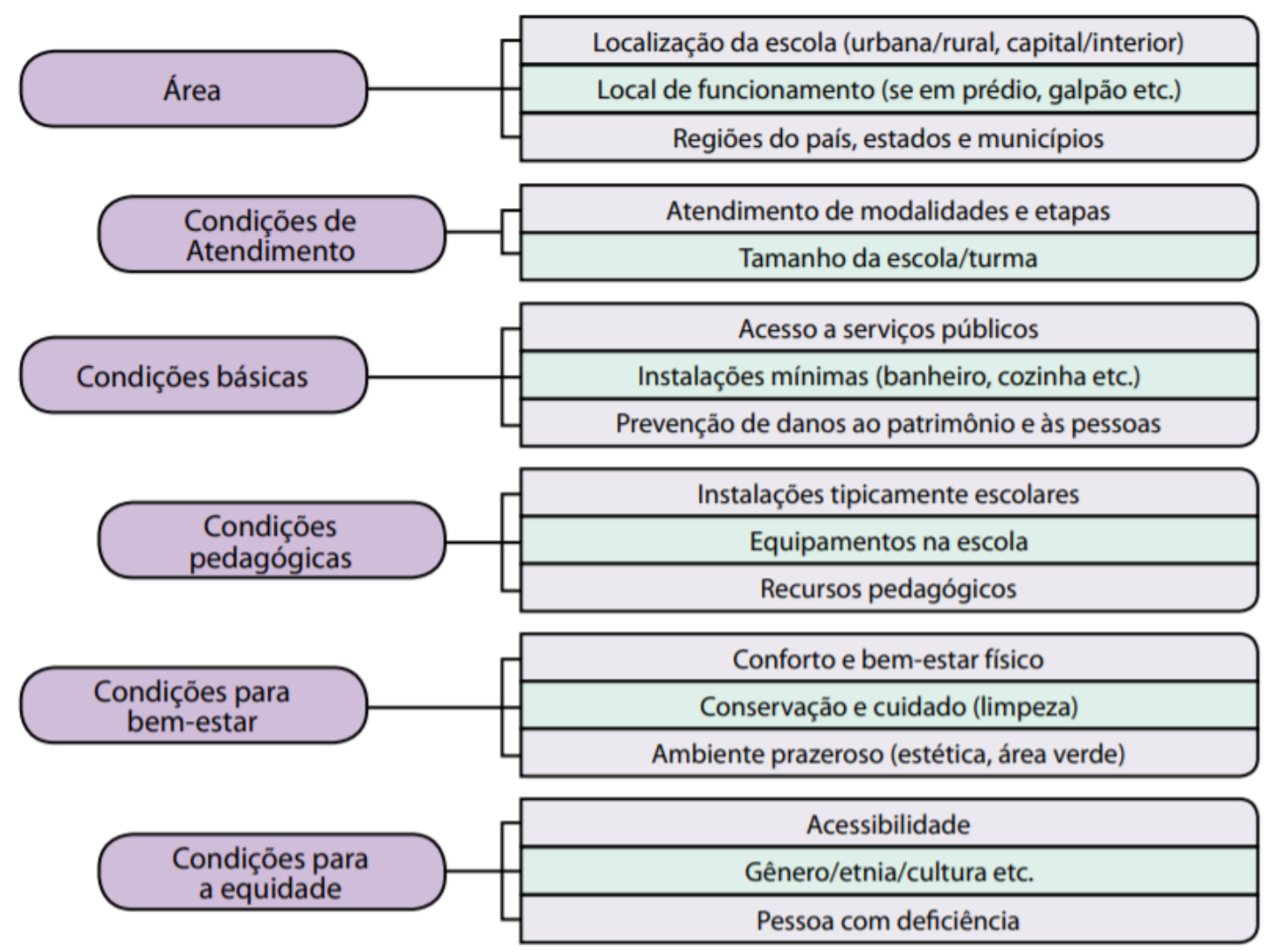

Fonte: UNESCO, 2019

Tais dimensões foram analisadas por funcionários e ex-funcionários, por meio de relatórios fotográficos e dados fornecidos pela instituição EEEFM Honório Fraga. Sendo a comissão de avaliadores composta por um dos autores deste trabalho, o qual trouxe a visão de um engenheiro civil, e por três profissionais que trabalharam em todas as etapas avaliadas nesse relatório: a diretora, uma pedagoga, e um ex-professor.

Os indicadores escolhidos para o desempenho foram os fornecidos pelo Instituto Nacional de Estudos e Pesquisas Educacionais Anísio Teixeira (Inep), e principalmente aqueles referentes ao ensino fundamental, devido à abundância de informações. Dentre os indicadores de desempenho, há o Sistema de Avaliação da Educação Básica (Saeb) que é:
Um conjunto de avaliações externas em larga escala que permite ao Inep realizar um diagnóstico da educação básica brasileira e de fatores que podem interferir no desempenho do estudante.

Por meio de testes e questionários, aplicados a cada dois anos na rede pública e em uma amostra da rede privada, o Saeb reflete os níveis de aprendizagem demonstrados pelos estudantes avaliados, explicando esses resultados a partir de uma série de informações contextuais (Inep, $\mathrm{s} / \mathrm{d})$.

Outro indicador de desempenho utilizado foi o Índice de desenvolvimento da educação básica (Ideb), criado em 2007, que reúne outros indicadores como média de desempenho nas avaliações e o fluxo 
escolar, entre outros, para aferir a qualidade da educação (Inep). Foram utilizados os dados relativos à educação fundamental por ter uma maior quantidade de dados em relação a outras modalidades de ensino que a escola abrange.

Vale ressaltar que os indicadores abordados possuem suas limitações metodológicas, mas foram adotados devido à abrangência de dados, além, também, de serem de cunho nacional.

\section{RESULTADOS E DISCUSSÃO}

No dia 23 de dezembro de 2009, o Instituto de Obras Públicas do Espírito Santo (Iopes) assinou o contrato da empresa vencedora da concorrência pública para a reconstrução da EEEFM
Honório Fraga, localizada na rua Nossa Senhora Aparecida n. 214, no Bairro São Silvano, cidade de Colatina/ES. E em setembro de 2010 iniciou-se a reconstrução da escola.

Antes da reconstrução, a infraestrutura escolar possuía problemas como infiltrações da água da chuva, devido a uma impermeabilização ineficaz da estrutura escolar, instalações elétricas precárias, dentre outros. A estrutura propriamente dita também estava bem aquém da adequada. Possuía sinais de instabilidade como fissuras, rachaduras, deformações excessivas, inclusive podendo colocar em risco a vida dos estudantes e trabalhadores, conforme apresentado na Figura 3. (a)

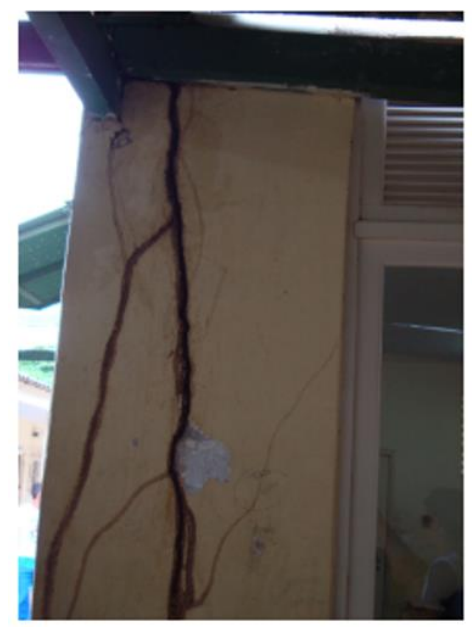

Fonte: Acervo do autor.

Figura 3: Problemas na estrutura escolar em 2008

(b)

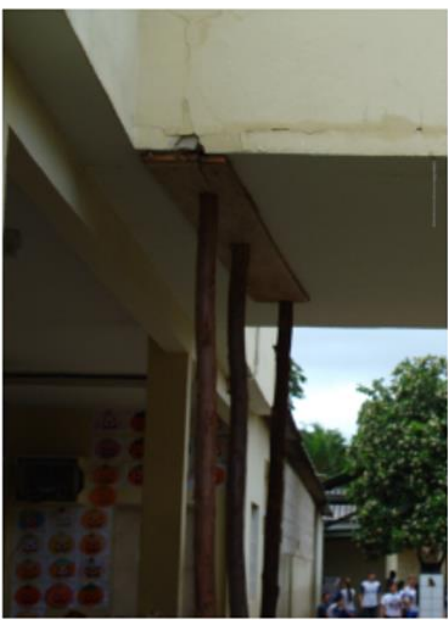

(c)

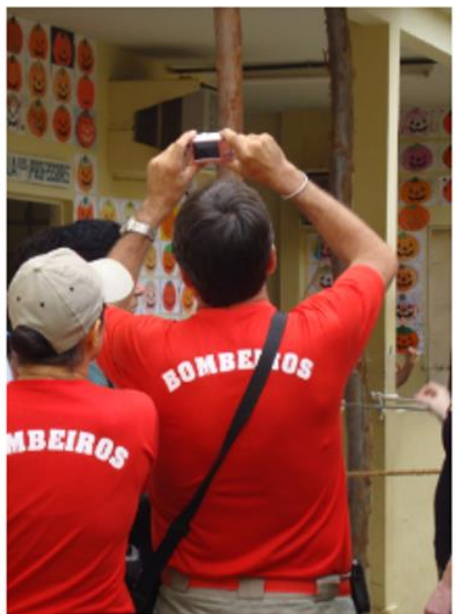

Então, em setembro de 2010, ocorreu a mudança de endereço da escola para a Av. Silvio Avidos, em um galpão provisório, para que a reconstrução da escola fosse realizada. $O$ galpão não possuía estruturas tipicamente escolares, sendo necessária a montagem de estruturas provisórias de paredes de gesso acartonado (drywall), como pode ser observado na Figura 4. 
Figura 4: (a) Sala de aula antes de 2010 (b) Sala de aula no galpão provisório (c) divisórias de

(a)

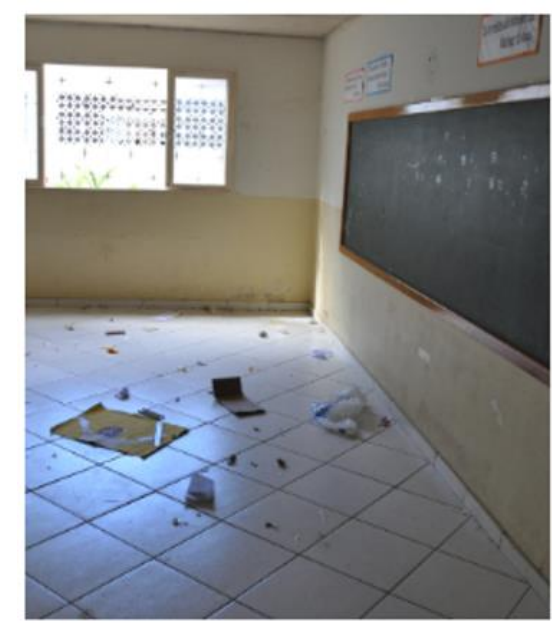

Fonte: Acervo do autor.

Tal mudança melhorou a estrutura em termos de segurança, porém as condições de bem-estar estavam aquém da adequada, principalmente em razão do calor que fazia no galpão, devido ao clima da cidade e também às telhas de zinco inapropriadas para o conforto térmico. Por esse motivo, no início do ano letivo de 2011, todas as salas foram equipadas com ar-condicionado, levando assim a um maior conforto aos usuários.

As telhas também traziam problemas em dias de chuvas fortes, pois o barulho da chuva atrapalhava os trabalhos na escola. A ausência de quadra e (b) (c)

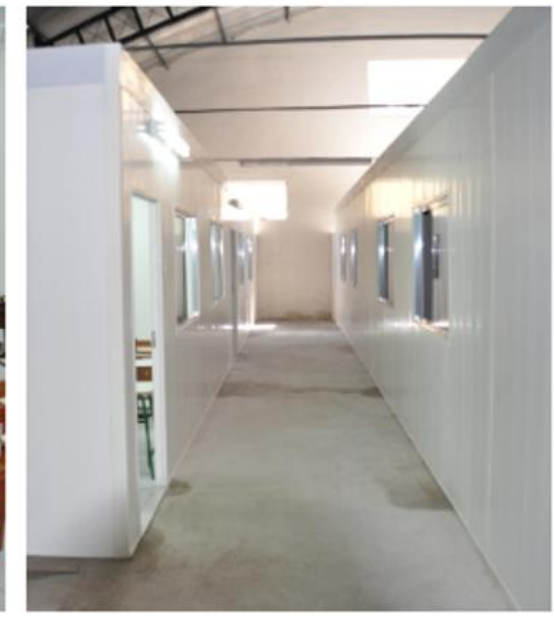

atividades esportivas no galpão também era um aspecto negativo, ressaltada a importância de tais atividades pelo PNE.

Em novembro de 2012, ocorreu nova mudança. Dessa vez, para a escola reconstruída e adequada para o ensino de qualidade. Agora, a instituição conta com condições de acessibilidade, rampa, plataforma elevatória, banheiro acessível, biblioteca adequada, duas salas de informática, laboratório de ciências, equipamentos mais condizentes com a prática pedagógica, entre outros, conforme mostrado na Figura 5. 
Figura 5: Fotos da escola reconstruída, após 2012: (a) Plataforma elevatória (b) Laboratório de ciências (c) Sala de aula (d) Laboratório de informática (e) Biblioteca

(a)

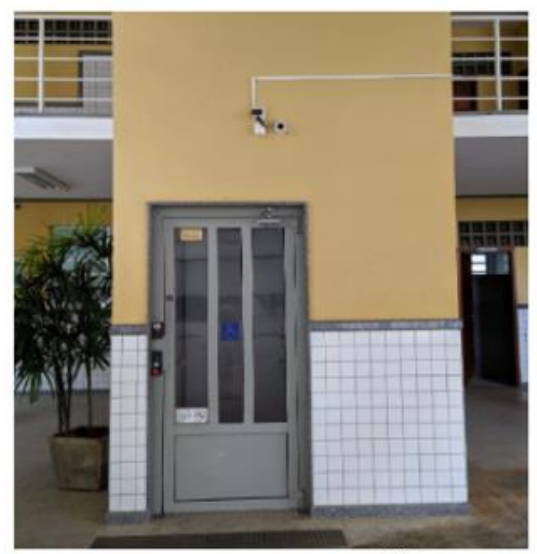

(d)

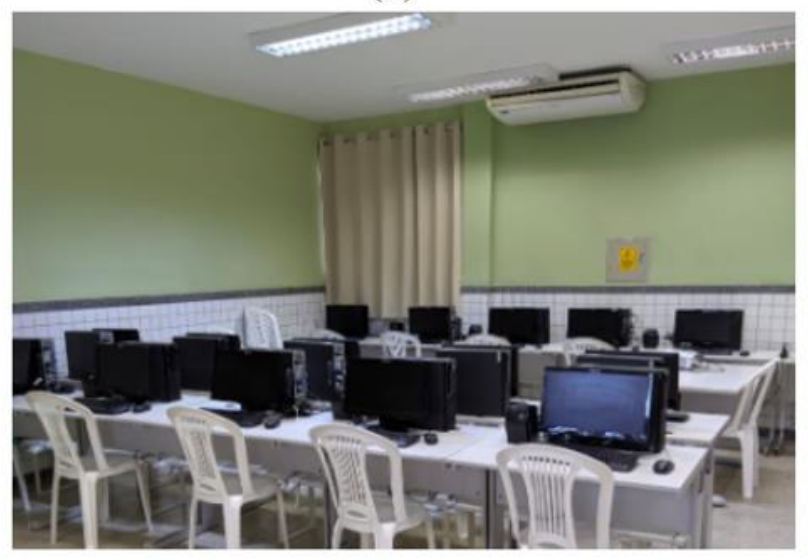

Fonte: Acervo de um dos autores

Fatores como a chuva que, antes de setembro de 2010, era um evento preocupante, depois da escola reconstruída virou uma solução, devido ao armazenamento da água da chuva para processos como limpeza e irrigação. Isso rendeu à escola, em 2016, o prêmio "boas práticas”, que é promovido pela Secretaria (b)

(c)

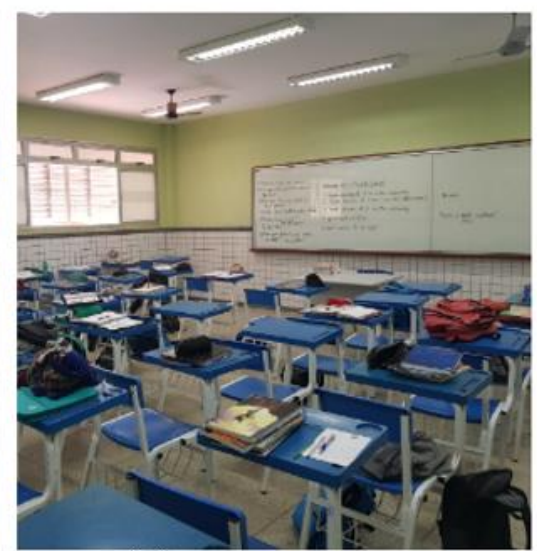

(e)

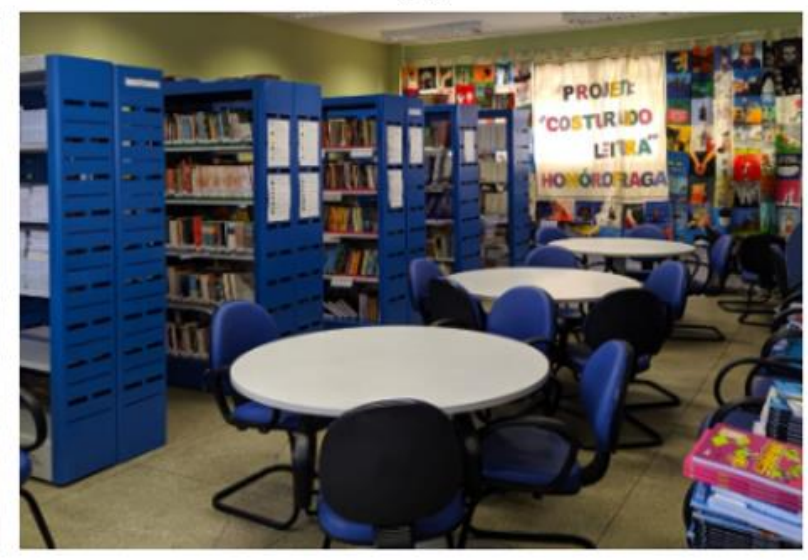

de Educação do Espírito Santo (Sedu) e tem como objetivo reconhecer os trabalhos daqueles que atuam na educação do estado do Espírito Santo, e que contribuíram para a qualidade da educação de forma relevante (SEDU, 2020). Veja-se a Figura 6 , referente às questões inerentes à chuva. 
Figura 6: (a) Mofo causado pelas chuvas de 2008 (b) Alagamento da quadra em 2008 (c) Reservatórios pluviais atuais

(a)

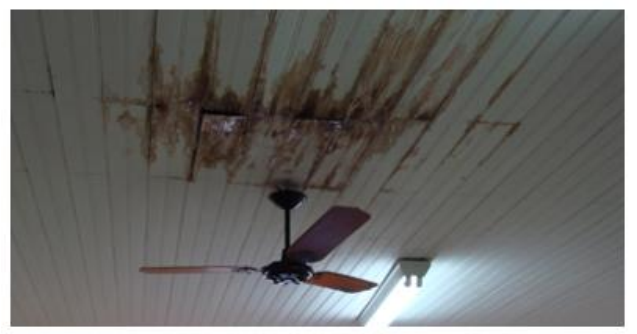

(b)

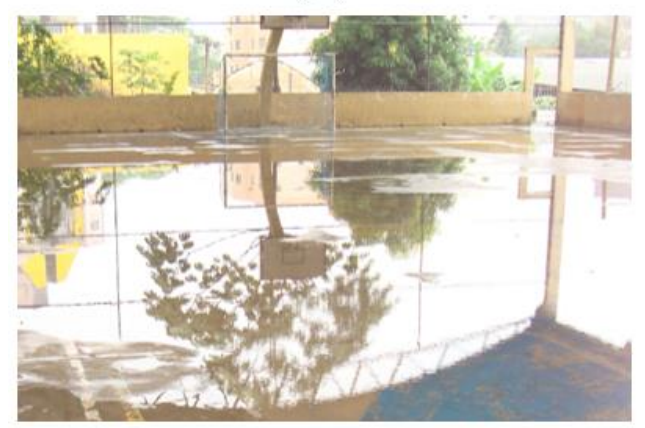

Fonte: Acervo de um dos autores

Em relação às condições de segurança, a escola reconstruída possui inclusive proteção contra incêndios, com extintores, sinalização de segurança, dentre outros itens de segurança.

Diversas comparações podem ser feitas entre a escola antes de 2010 e a reconstruída, dentre elas dos equipamentos pedagógicos. Ambientes administrativos, externos, salas de aula também tiveram mudanças significativas.

Em uma forma de mensuração da infraestrutura das diversas fases, o Quadro 1 foi elaborado a partir de um relatório de (c)

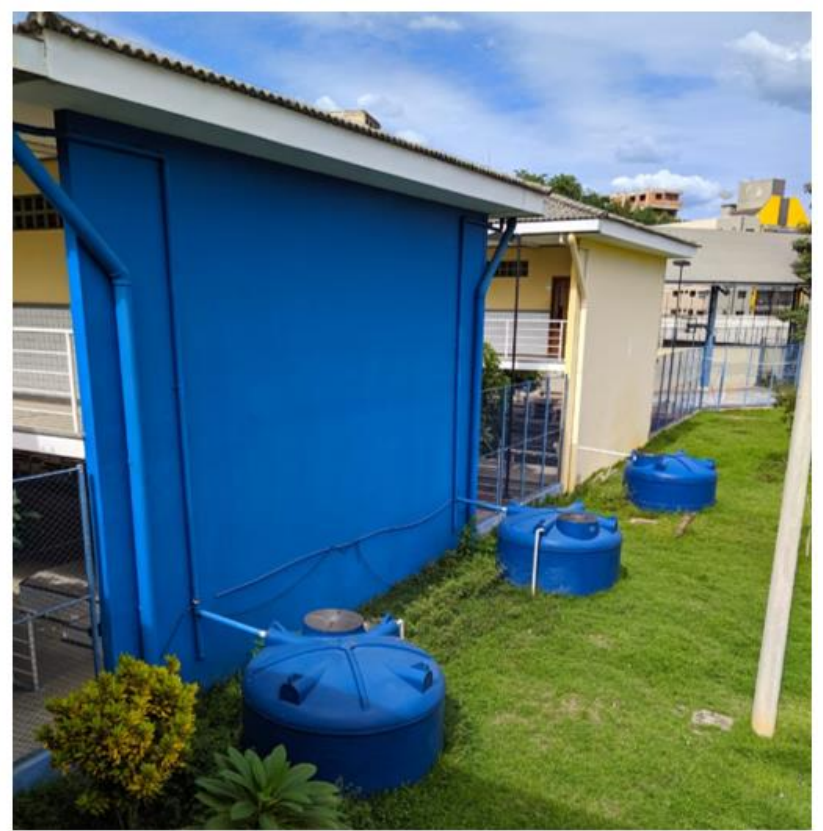

avaliação da infraestrutura. Para tal, foi organizada uma comissão. Esta foi composta por quatro membros, sendo um deles um dos autores deste trabalho, que contribuiu com a visão de engenheiro civil. Tais membros acompanharam todas as fases de mudanças da infraestrutura da escola. A pontuação destinada à valoração do que foi mensurado, em termos de dimensão e indicador, no relatório, estabeleceu-se de 1, péssimo, com condições totalmente inadequadas ao ensino, até 5, ótimo, excelentes condições para a aprendizagem. 
Quadro 1: Relatório da infraestrutura da EEEFM Honório Fraga nas diversas fases

\begin{tabular}{|c|c|c|c|c|}
\hline DIMENSÃO & INDICADOR & $\begin{array}{c}\text { Escola até } \\
\text { setembro } \\
\text { de } 2010\end{array}$ & $\begin{array}{l}\text { Galpão } \\
\text { Provisório }\end{array}$ & $\begin{array}{c}\text { Escola } \\
\text { após } \\
\text { novembro } \\
\text { de } 2012\end{array}$ \\
\hline \multirow{3}{*}{ Área } & $\begin{array}{l}\text { Localização da escola } \\
\text { (urbana/rural, capital/interior) }\end{array}$ & 5 & 4 & 5 \\
\hline & $\begin{array}{l}\text { Local de funcionamento (se em } \\
\text { prédio, galpão etc.) }\end{array}$ & 3 & 2 & 5 \\
\hline & $\begin{array}{l}\text { Regiões do país, estados e } \\
\text { municípios }\end{array}$ & 4 & 4 & 4 \\
\hline \multirow{2}{*}{$\begin{array}{l}\text { Condições de } \\
\text { Atendimento }\end{array}$} & $\begin{array}{l}\text { Atendimento de modalidades e } \\
\text { etapas }\end{array}$ & 4 & 4 & 5 \\
\hline & Tamanho da escola/turma & 3 & 3 & 5 \\
\hline \multirow{3}{*}{ Condições básicas } & Acesso a serviços públicos & 4 & 4 & 5 \\
\hline & $\begin{array}{l}\text { Instalações mínimas (banheiro, } \\
\text { cozinha etc.) }\end{array}$ & 2 & 3 & 5 \\
\hline & $\begin{array}{l}\text { Prevenção de danos ao patrimônio } \\
\text { e às pessoas }\end{array}$ & 1 & 4 & 5 \\
\hline \multirow{3}{*}{$\begin{array}{l}\text { Condições } \\
\text { pedagógicas }\end{array}$} & Instalações tipicamente escolares & 2 & 3 & 5 \\
\hline & Equipamentos na escola & 3 & 3 & 5 \\
\hline & Recursos pedagógicos & 4 & 4 & 5 \\
\hline \multirow{3}{*}{$\begin{array}{l}\text { Condições para } \\
\text { bem-estar }\end{array}$} & Conforto e bem-estar físico & 1 & 3 & 4 \\
\hline & Conservação e cuidado (limpeza) & 2 & 3 & 5 \\
\hline & $\begin{array}{l}\text { Ambiente prazeroso (estética, área } \\
\text { verde) }\end{array}$ & 1 & 1 & 5 \\
\hline \multirow{3}{*}{$\begin{array}{c}\text { Condições para a } \\
\text { equidade }\end{array}$} & Acessibilidade & 2 & 3 & 5 \\
\hline & Gênero/etnia/cultura etc. & 3 & 3 & 5 \\
\hline & Pessoa com deficiência & 3 & 3 & 5 \\
\hline \multicolumn{2}{|r|}{ MÉDIA } & 2,76 & 3,18 & 4,88 \\
\hline Péssimo & Regular & Bom & Ótimo & \\
\hline
\end{tabular}

Fonte: BRAIDO et al., 2020

Como pode ser visto no Quadro 1, a melhoria da infraestrutura, do início de 2010 ao fim de 2012, foi bem considerável, principalmente o índice médio da escola reconstruída que é quase ótimo $(4,88)$. Sendo as condições básicas e de bem-estar as que tiveram as maiores mudanças.
O Gráfico 1 retrata a correlação da evolução da infraestrutura com indicadores educacionais (Ideb e Saeb) da EEEFM Honório Fraga de 2005 a 2017. 
Gráfico 1: Comparação de índices de desempenho educacional (Ideb e Saeb) com o indicador da infraestrutura da EEEFM Honório Fraga

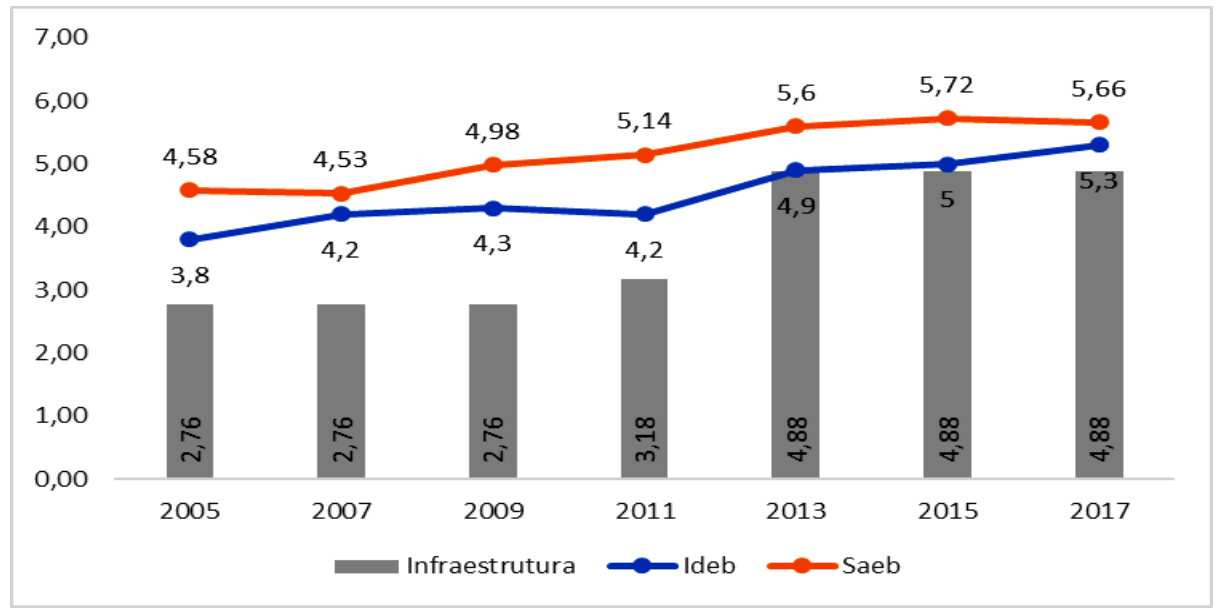

Fonte: Adaptado do Inep

A comparação de índices de desempenho educacional, no Gráfico 1 , foi organizada de dois em dois anos, uma vez que o Ideb é divulgado a cada dois anos. Vale ressaltar que as mudanças de infraestrutura ocorreram na EEEFM Honório Fraga em 2010, da escola "antiga" para o galpão provisório, e em 2012, do galpão provisório para a escola reconstruída. Logo, o índice percentual da infraestrutura, do Ideb e do Saeb de 2010 será analisado tendo por base a diferença percentual obtida do ano de 2011 em referência ao de 2009. O mesmo será realizado do ano de 2011 para o de 2013. A comparação entre tais índices torna-se mais clara ao observarmos o Gráfico 2.

Gráfico 2: Comparação da variação (\%) dos índices educacionais (Ideb e Saeb) e do indicador de infraestrutura entre os anos de 2009 e 2011 e os anos de 2011 e 2013

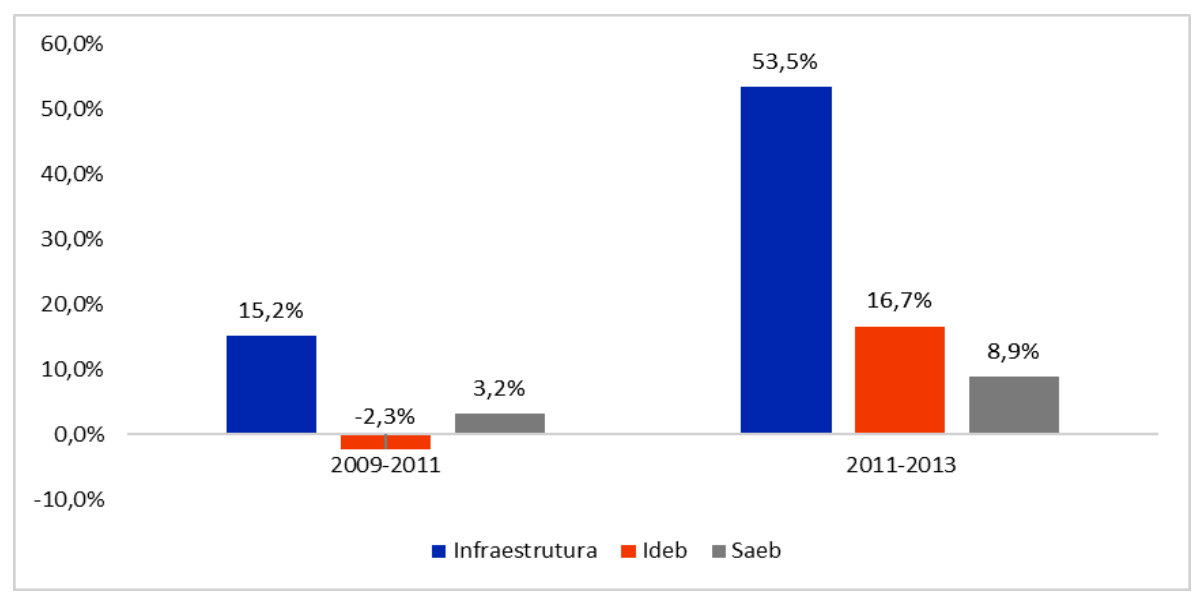

Fonte: Adaptado do Inep

Pelo Gráfico 2, percebe-se que em 2009/2011 a infraestrutura apresentou um pequeno incremento $15,2 \%$, na mudança da escola "antiga" para o galpão provisório. Porém, em relação aos indicadores educacionais não houve uma mudança significativa, uma vez que o Ideb diminuiu $-2,3 \%$ e o Saeb aumentou $3,2 \%$.

A ausência de uma correlação entre o desempenho estudantil e a melhoria da infraestrutura, entre 2009 e 2011, está provavelmente relacionada, veja-se o Quadro 1, à pequena variação da qualidade 
da infraestrutura da escola antiga $(2,76)$, de ruim a regular, para o galpão $(3,18)$, de regular a bom, mesmo não sendo $\mathrm{o}$ adequado para um ensino de qualidade.

Já a variação dos índices, na mudança, em 2012, do galpão provisório para a escola reconstruída foi bastante expressiva, aumento de $53,5 \%$ na infraestrutura, de 16,7\% no Ideb e de $8,9 \%$ no Saeb. Validando essa assertiva, tem-se, no Quadro 1, a qualidade da infraestrutura, considerada como ótima $(4,88)$, após novembro de 2012.

Importante destacar que se forem retomadas as respostas do questionário aplicado aos discentes e servidores da EEEFM Honório Fraga, conforme pode ser observado nos Gráficos 3 e 4, nota-se que, ao se realizar uma análise comparativa, não houve uma conclusão clara em relação à mudança da infraestrutura no desempenho escolar dos alunos, quando da mudança para o galpão provisório.

Uma hipótese na ausência de alteração para muitos alunos, conforme observado no Gráfico 3, pode ser devido à ausência de mudanças dos professores no espaço da sala de aula e à necessidade de outros tipos de atividades, como as atividades físicas, contrabalanceando a percepção dos estudantes.

Gráfico 3: Respostas ao questionário em relação à mudança de infraestrutura da

escola antes de 2010 para o galpão provisório - alunos e ex-alunos

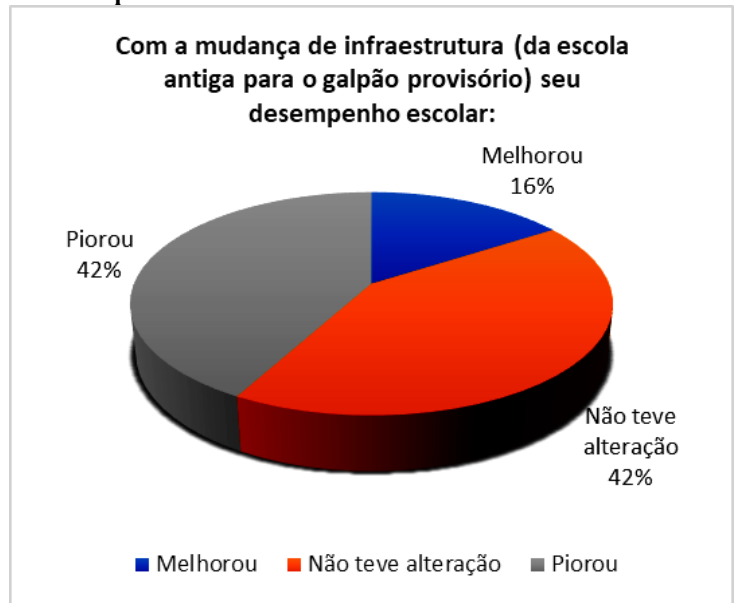

Fonte: Elaborado pelos autores
Gráfico 4: Respostas ao questionário em relação à mudança de infraestrutura da escola antes de 2010 para o galpão provisório - funcionários e ex-funcionários

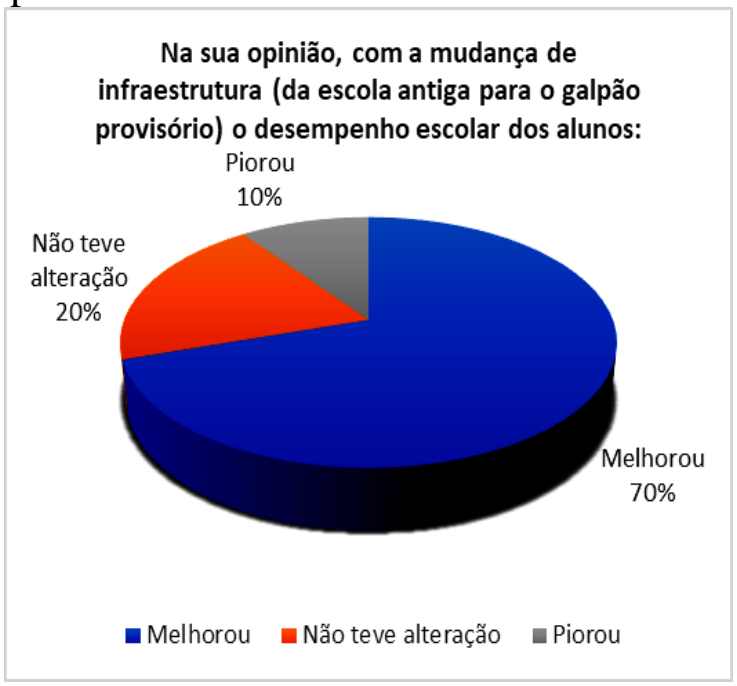

Fonte: Elaborado pelos autores

Em análise do Gráfico 3, tem-se que para $42 \%$ dos discentes não houve alteração no desempenho escolar com a ida para o galpão provisório. No entanto, com mesmo percentual $42 \%$, outros afirmaram que piorou. Somente $16 \%$ consideraram ter ocorrido uma melhoria no desempenho acadêmico.

Em contrapartida, ao se observar o Gráfico 4, é notório uma discrepância dos funcionários e ex-funcionários em relação à opinião dos alunos quanto à melhoria do desempenho acadêmico. Há uma disparidade clara entre os dois segmentos. Tal diferença deva-se, talvez, ao relato dos alunos e ex-alunos que consideraram como fatores de importância para um possível mau desempenho escolar a área externa inadequada e ausência de quadra e atividades esportivas, conforme pode ser visto no Gráfico 5, aspectos estes que não pesaram na opinião dos funcionários e exfuncionários. 
Gráfico 5: Respostas ao questionário dos alunos e ex-alunos sobre os aspectos que ajudaram a piorar o desempenho deles na mudança de infraestrutura da escola antes de 2010 para o galpão provisório

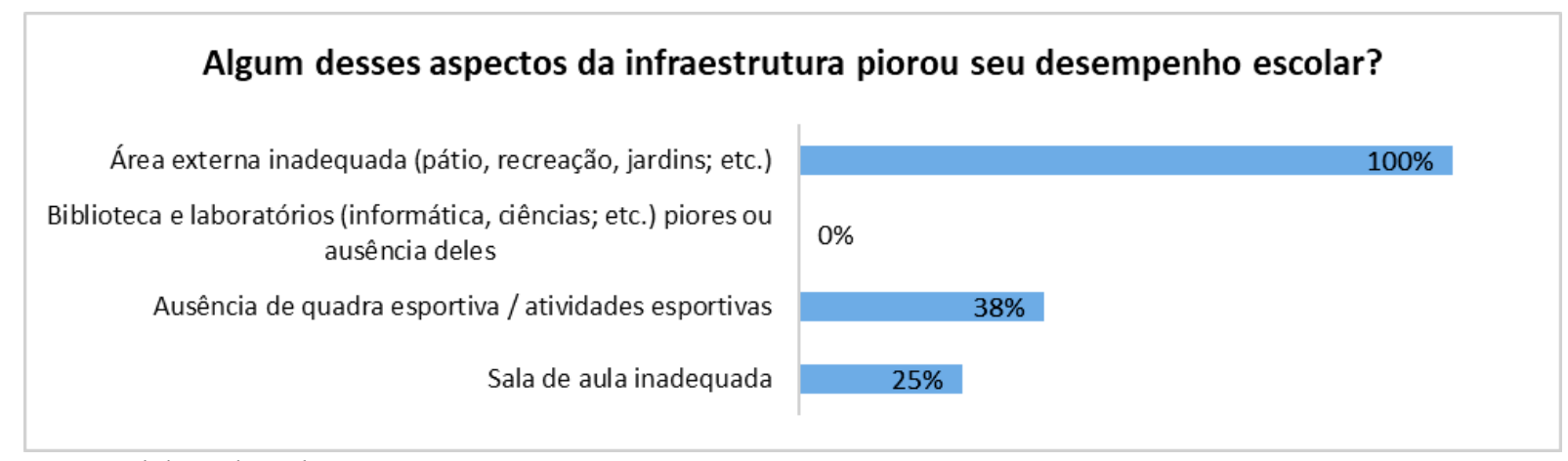

Fonte: Elaborado pelos autores

Todos os alunos participantes $(100 \%)$ responderam que a área externa inadequada é um aspecto da infraestrutura que piorou o desempenho escolar. Nenhum deles $(0 \%)$ considerou que biblioteca e laboratórios engendravam uma percepção, enquanto questões de infraestrutura, responsáveis por uma piora no desempenho acadêmico. A sala de aula, em termos performance escolar, foi menos impactante para $25 \%$ dos alunos do que a ausência de quadra e atividades esportivas $(38 \%)$. Eis, como dito anteriormente, as possíveis causas da diferença de percepção entre alunos e servidores quanto à opinião acerca da relação entre mudança de infraestrutura e desempenho escolar: área externa adequada, quadra e atividades esportivas.

No entanto, se o olhar voltar-se para a mudança de infraestrutura referente ao ano de 2012, haverá mais um consenso, a ser agregado ao que está explicitado no Quadro 1 e no Gráfico 2. O referido consenso foi buscado na opinião dos alunos e ex-alunos e dos funcionários e exfuncionários, referenciados no questionário aplicado, como mostram os Gráficos 6 e 7.
Gráfico 6: Respostas ao questionário em relação à mudança de infraestrutura do galpão provisório para a escola reconstruída - alunos e ex-alunos

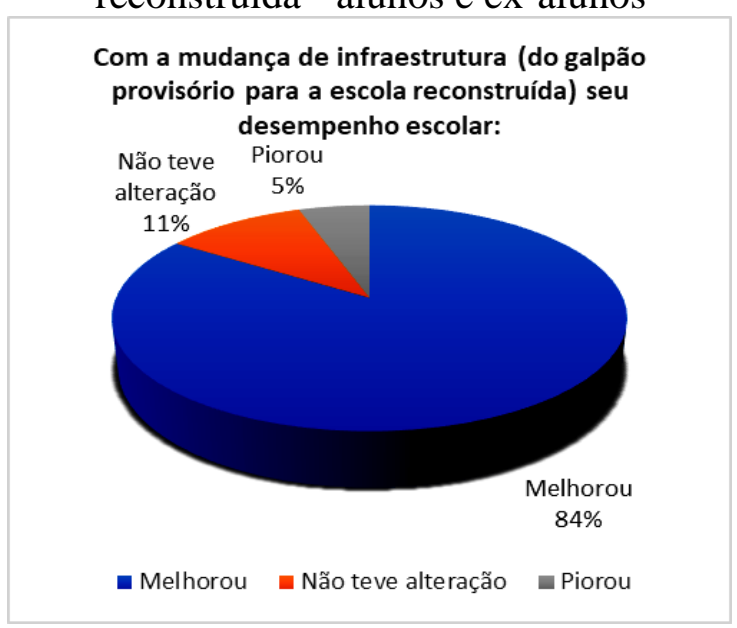

Fonte: Elaborado pelos autores 
Gráfico 7: Respostas ao questionário em relação à mudança de infraestrutura do galpão provisório para a escola reconstruída - funcionários e exfuncionários

Na sua opinião, com a mudança de infraestrutura
(do galpão provisório para a escola reconstruída) o desempenho escolar dos alunos:

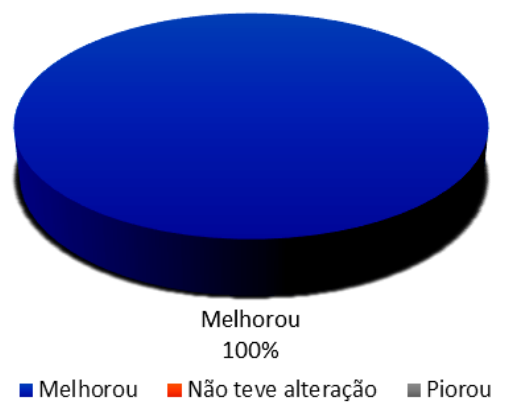

Fonte: Elaborado pelos autores
A análise realizada, no comparativo dos Gráficos 8 e 9, evidencia que a maioria dos respondentes do questionário considera que a mudança da infraestrutura, do galpão para a escola reconstruída, melhorou o desempenho escolar. Desses, $100 \%$ foram funcionários e $84 \%$ alunos. Da totalidade dos alunos, $5 \%$ afirmam ter piorado e $11 \%$ não ter tido alteração.

Muitos foram os fatores que conduziram a um percentual tão positivo. Os Gráficos 8 e 9 evidenciam os aspectos que possibilitaram a efetiva e eficaz mudança.

Gráfico 8: Respostas ao questionário dos alunos e ex-alunos que responderam que a mudança de infraestrutura do galpão provisório para a escola reconstruída melhorou o desempenho deles, em relação a quais aspectos da infraestrutura levaram a isso

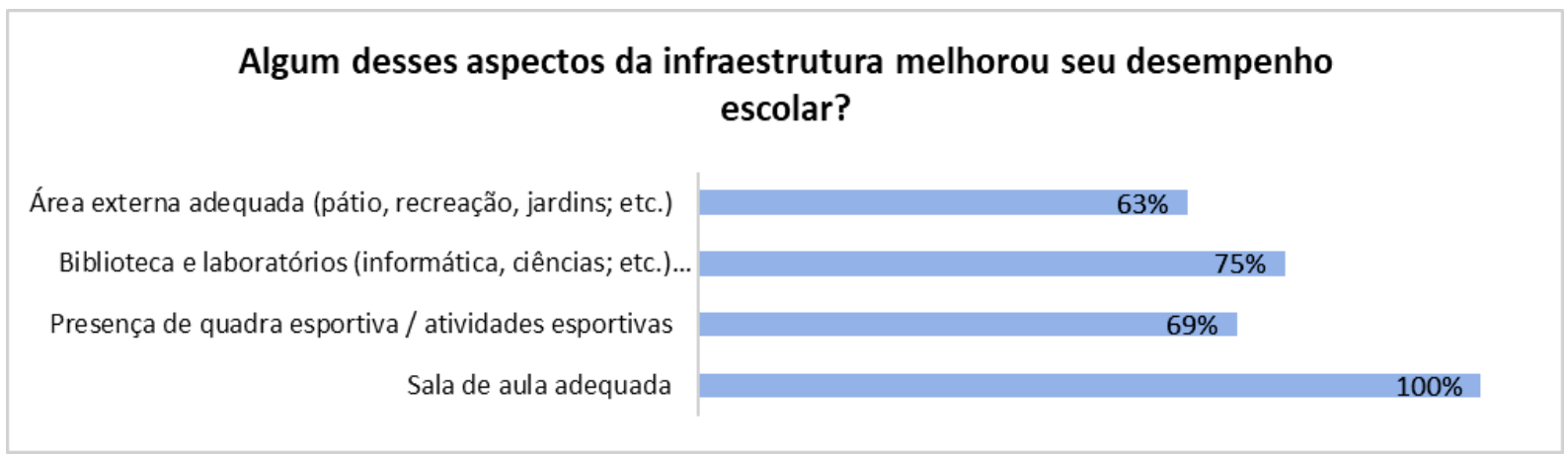

Fonte: Elaborado pelos autores

Gráfico 9: Respostas ao questionário dos funcionários e ex-funcionários que responderam que a mudança de infraestrutura do galpão provisório para a escola reconstruída melhorou o desempenho dos alunos, em relação a quais aspectos da infraestrutura levaram a isso

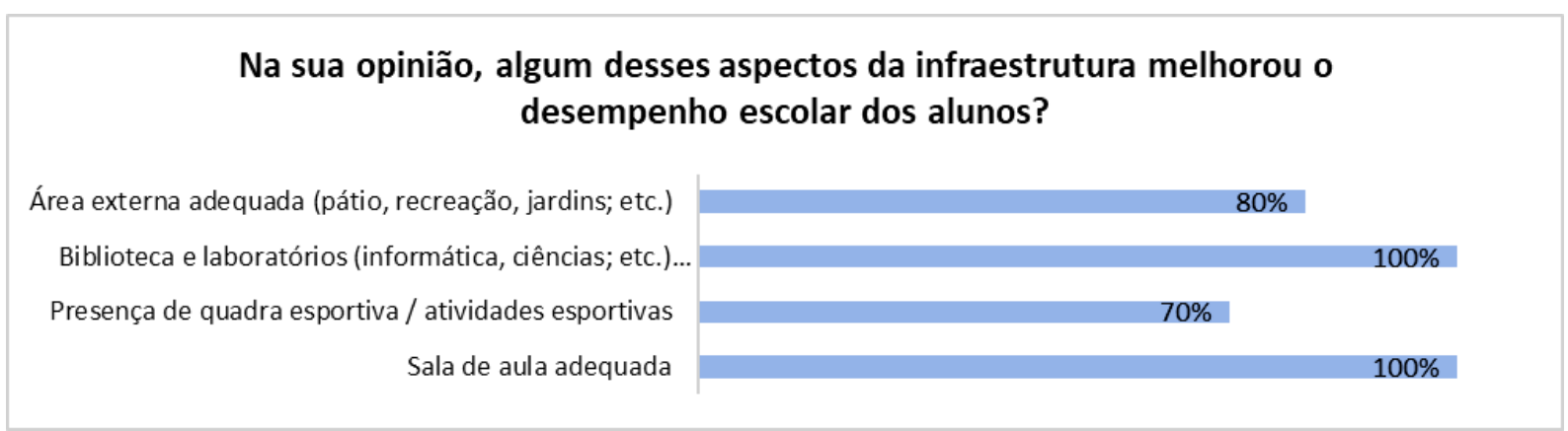

Fonte: Elaborado pelos autores 
Ao comparar os Gráficos 8 e 9, fica evidente que todos os participantes da pesquisa assinalaram que ter uma sala de aula adequada melhorou o desempenho escolar. Foram 100\% das respostas dos alunos e $100 \%$ das dos funcionários. A biblioteca e os laboratórios adequados foram considerados como aspecto de melhoria no desempenho por $75 \%$ dos alunos e $80 \%$ dos funcionários. A presença de quadra esportiva foi escolhida por $69 \%$ dos alunos e $70 \%$ dos funcionários, como fator importante de melhora no desempenho. Por fim, a área externa por $63 \%$ dos estudantes e $80 \%$ dos funcionários. Isso dá a ver a correlação direta entre a infraestrutura escolar e o desempenho estudantil. Esse é mais um aspecto que valida o entendimento dos alunos quando em resposta ao que está tabulado no Gráfico 5, ou seja, que o desempenho escolar tem extrema relação com aspectos de infraestrutura referentes à área externa e quadra para atividades esportivas adequadas.

Outros indicadores que corroboram com a correlação entre a influência da infraestrutura e o desempenho escolar são evidenciados nos Gráficos 10 e 11.

Gráfico 10: Respostas ao questionário dos alunos e ex-alunos em relação a quais fatores facilitam a aprendizagem deles

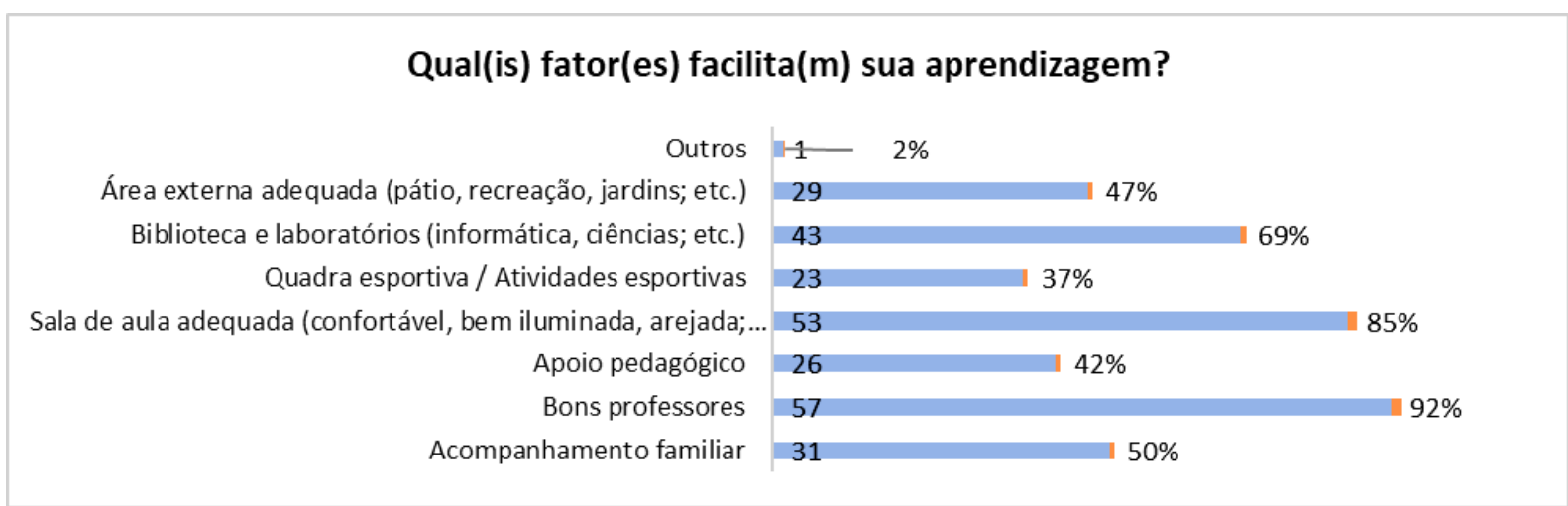

Fonte: Elaborado pelos autores

Gráfico 11: Respostas ao questionário dos funcionários e ex-funcionários em relação a quais fatores facilitam no processo de ensino-aprendizagem

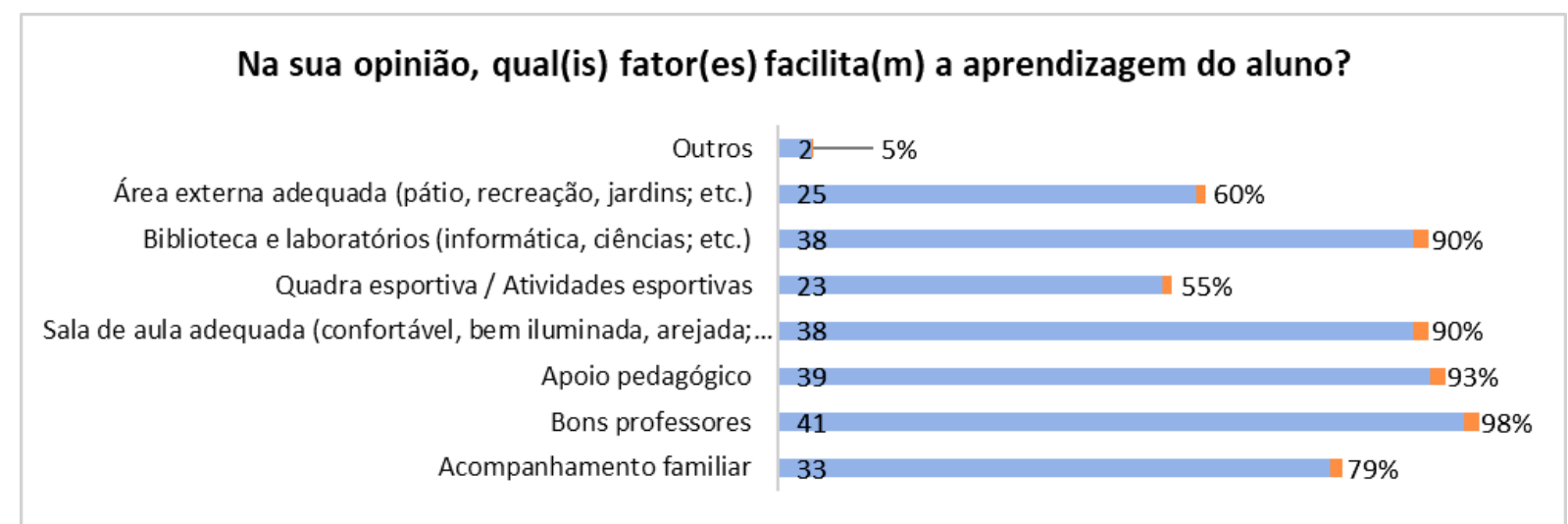

Fonte: Elaborado pelos autores

Os Gráficos 10 e 11 mostram, em consonância com os Gráficos 8 e 9, a importância de uma sala de aula adequada para o êxito escolar. Não sem motivo, para $85 \%$ dos estudantes e $90 \%$ dos funcionários uma sala de aula adequada 
facilita a aprendizagem. Da mesma forma, para $69 \%$ dos alunos e $90 \%$ dos funcionários a presença de biblioteca e laboratórios também facilita, dentre outros itens citados como área externa adequada, $47 \%$ e $60 \%$, e quadra esportiva, $37 \%$ e $55 \%$, respectivamente.

Deve-se enfatizar que outros fatores foram levados em consideração nos questionários, não sendo eles excludentes à infraestrutura, possuindo grande influência no desempenho escolar. Como exemplo, tem-se a importância de haver bons professores para facilitar a aprendizagem, sendo que $92 \%$ dos alunos e $98 \%$ dos funcionários responderam que esse aspecto facilita no desempenho estudantil.

Aspectos como apoio pedagógico, acompanhamento familiar e interesse dos alunos, do mesmo modo, foram citados como fatores de relevantes no processo de ensino-aprendizagem. Tem-se, associado aos aspectos da infraestrutura, o fator da competência e comprometimento dos envolvidos no processo de ensinoaprendizagem. Sendo assim, estes e a infraestrutura adequada resume-se a uma união fundamental para auxiliar, em muito, no desempenho escolar dos alunos.

Pelos indicadores citados e a correlação entre eles, nota-se que fatores de infraestrutura do prédio escolar estão relacionados à melhora no processo de ensino-aprendizagem. Além de outros parâmetros também observados, como o abandono estudantil. Há que se considerar a importância do investimento na infraestrutura, ponto necessário, para a melhoria do desempenho dos alunos.

\section{CONCLUSÕES}

O presente artigo propôs o estudo da influência da infraestrutura no desempenho escolar, por meio do estudo de caso apresentado, focando nas mudanças de infraestrutura que a EEEFM Honório Fraga teve em comparação com variação do desempenho estudantil influenciado por essas transições.

A linha de tempo da infraestrutura EEEFM Honório Fraga revelou que antes de 2010 era considerada de ruim para regular (2,76); passando para o galpão provisório, de regular para bom $(3,18)$; e após 2012, para a escola reconstruída, de bom para ótimo $(4,88)$. Em linhas de equiparação temos o Ideb e o Saeb. O Ideb seguiu de 4,3 em 2009, 4,2 em 2011 e 4,9 em 2013. Já o Saeb com 4,98 em 2009, 5,14 em 2011 e 5,6 em 2013.

Foi possível perceber uma grande variação de indicadores de 2011 para 2013, justamente após a mudança para a escola reconstruída, mostrando uma melhora de $53,5 \%$ na infraestrutura, de $16,7 \%$ no Ideb e de $8,9 \%$ no Saeb.

Indicadores de desempenho estudantil, como Ideb e Saeb, por exemplo, puderam ser relacionados a diversos fatores, dentre eles, a infraestrutura, como foi observado na mudança entre o galpão provisório e a escola reconstruída. Tal correlação foi percebida também na opinião de alunos e funcionários que atribuíram fatores intrínsecos à infraestrutura como importantes para o ensino-aprendizagem.

As informações surgidas, devido à colaboração dos participantes para efetivação desta pesquisa, corroboram com os estudos da Unesco que indicam a relação de melhores indicadores de desempenho estudantil nas escolas com melhores infraestruturas (UNESCO, 2019).

Esta pesquisa trouxe para a discussão a importância da infraestrutura na aprendizagem dos alunos, destacando fatores como a adequação das salas de aula, recursos pedagógicos adequados como laboratórios de ciências, de informática, uma boa biblioteca, dentre outros itens evidenciados neste artigo.

Portanto, este estudo de caso mostra que se deve dar a devida importância à infraestrutura escolar, 
objetivando o bem-estar estudantil e condições para equidade e acessibilidade nas escolas públicas da educação municipal, estadual e federal.

\section{AGRADECIMENTOS}

O desenvolvimento deste trabalho contou com a ajuda direta e indireta de diversas pessoas. Agradeço à minha orientadora, por esclarecer minhas dúvidas, a todos que responderam o questionário, e à diretora, às pedagogas e aos professores da EEEFM Honório Fraga.

\section{REFERÊNCIAS}

ALVES, Maria Teresa Gonzaga; FRANCO, Creso. A pesquisa em eficácia escolar no Brasil: evidências sobre o efeito das escolas e fatores associados à eficácia escolar. In: BROOKE, Nigel; SOARES, Francisco. (orgs.) Pesquisa em eficácia escolar: origem e trajetórias. Belo Horizonte: Editora UFMG, 2008. p.482500.

BRAIDO, Leonan Stôccoet al. Relatório de Infraestrutura Escolar. EEEFM Honório Fraga. Colatina, 2020.

BRAIDO, Maria da Glória Stôcco; et al. Plano de Desenvolvimento Institucional (PDI). EEEFM Honório Fraga. Colatina, 2019.

BRASIL. Constituição (1988). Constituição da República Federativa do Brasil. Brasília, DF: Senado Federal, 1988. Disponível em:

<http://www.planalto.gov.br/ccivil_03/Con stituicao/Constituicao.htm>. Acesso em: 10 jan. 2020.

BRASIL, Lei n. 9394, de 20 de dezembro de 1996, Lei de Diretrizes e Bases da Educação Nacional. Brasília, DF: Senado Federal, 1996. Disponível em: <http://www.planalto.gov.br/ccivil_03/leis/ 19394.htm> Acesso em: 15 fev. 2020.

BRASIL. Lei n. 13.005, de 25 de junho de 2014. Aprova o Plano Nacional de Educação e dá outras providências. Diário Oficial da União, Brasília, 26 jun. 2014.

\section{CNE/CEB. Define Diretrizes}

Curriculares Nacionais Gerais para a Educação Básica, Resolução n. 4, de 13 de julho de 2010.

GAMORAN, Adam; SECADA, Walter; MARRETT, Cora. The Organizational Context of Teaching and Learning: Changing Theoretical Perspectives. Editora: M. Hallinan. Handbook of the Sociology of Education, Springer. Nova Iorque, 2000. Disponível em: $<$ https://pdfs.semanticscholar.org/a5a2/d57 25bcfbcf3e161706903df1a21cecc9775.pdf > Acesso em: 23 fev. 2020.

GIL, Antonio Carlos. Métodos e Técnicas de Pesquisa Social. 6a. ed. São Paulo: Editora Atlas S.A., 2008.

GRUBER, Arthur. Covid-19: o que se sabe sobre a origem da doença. Jornal da USP, 2020. Disponível em: < https://jornal.usp.br/artigos/covid2-oquese-sabe-sobre-a-origem-da-doenca/> . Acesso em: 10 maio 2020.

GT CAQ. Relatório final do Grupo de Trabalho constituído com a finalidade de elaborar estudos sobre a implementação do Custo Aluno Qualidade - CAQ, como parâmetro para o financiamento da educação básica. Brasília: GT CAQ, maio 2015.

INEP - Instituto Nacional de Estudos e Pesquisas Educacionais Anísio Teixeira. Indicadores Educacionais. Disponível em: <http://portal.inep.gov.br/indicadoreseducacionais $>$. Acesso em: 30 set. 2019. 
IOPES - Instituto de Obras Públicas do Espírito Santo. Obras do Estado.

Disponível em:

$<$ https://transparencia.es.gov.br/Obras/Obr asGeral/Pesquisar?\&filtrar >. Acesso em: 08 abr. 2020.

OCDE. PISA 2012 Results: What Makes Schools Successful? Resources, Policies and Practices (Volume IV). PISA, OCDE Publishing, 2013. Disponível em: $<$ https://doi.org/10.1787/9789264201156en> Acesso em: 22 jan. 2020.

OCDE. PISA 2018 Results (Volume II): Where All Students Can Succeed. PISA, OCDE Publishing. Paris, 2019. Disponível em: 〈https://doi.org/10.1787/b5fd1b8f-en> Acesso em: 22 jan. 2020.

\section{SEDU. Prêmio Sedu Boas Práticas na}

Educação. Disponível em:

$<$ http://premioboaspraticas.sedu.es.gov.br/ $>$ Acesso em: 06 de jul. 2020.

UNESCO. Incheon Declaration.

Education 2030: towards inclusive and equitable quality education and lifelong learning for all. Paris, 2015.

\section{UNESCO. Qualidade da infraestrutura} das escolas públicas do ensino fundamental no Brasil. Brasília: Unesco, 2019. Disponível em: < http://www.crianca.mppr.mp.br/arquivos/F ile/publi/educacao_qualidade/qualidade_in fraestrutura_escolas_publicas_unesco_201 9.pdf>. Acesso em: 17 jan. 2020. 